ARTICLE

https://doi.org/10.1038/s41467-019-11503-3

\title{
The antimicrobial peptide thanatin disrupts the bacterial outer membrane and inactivates the NDM-1 metallo- $\beta$-lactamase
}

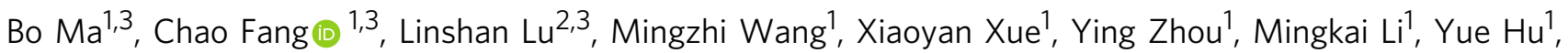
Xiaoxing Luo ${ }^{1} \&$ Zheng Hou (i) ${ }^{1}$

New Delhi metallo- $\beta$-lactamase-1 (NDM-1) is the most prevalent type of metallo- $\beta$-lactamase and hydrolyzes almost all clinically used $\beta$-lactam antibiotics. Here we show that the antimicrobial peptide thanatin disrupts the outer membrane of NDM-1-producing bacteria by competitively displacing divalent cations on the outer membrane and inducing the release of lipopolysaccharides. In addition, thanatin inhibits the enzymatic activity of NDM-1 by displacing zinc ions from the active site, and reverses carbapenem resistance in NDM-1producing bacteria in vitro and in vivo. Thus, thanatin's dual mechanism of action may be useful for combating infections caused by NDM-1-producing pathogens.

\footnotetext{
${ }^{1}$ Department of Pharmacology, School of Pharmacy, Fourth Military Medical University, Xi'an 710032, China. ${ }^{2}$ Department of Obstetrics and Gynecology, Tangdu Hospital, Fourth Military Medical University, Xi'an 710038, China. ${ }^{3}$ These authors contributed equally: Bo Ma, Chao Fang, Linshan Lu.

Correspondence and requests for materials should be addressed to X.L. (email: xxluo3@fmmu.edu.cn) or to Z.H. (email: hzh_0001@163.com)
} 
$\mathrm{N}$ ew Delhi metallo- $\beta$-lactamase-1 (NDM-1)-producing bacteria have been rapidly developing resistance to almost all antibiotics, including carbapenems ${ }^{1,2}$. The extensive horizontal transfer of $b l a_{\mathrm{NDM}-1}$ among various types of Gramnegative strains, especially Escherichia coli (E. coli) and Klebsiella pneumonia ( $K$. pneumoniae), accelerates the severe global spread of the gene $e^{3,4}$. In addition, $b l a_{\mathrm{NDM}-1}$ intercalates into existing resistance genes and evolutionarily generates new mutants. Previous studies reported that the resistance gene $m c r-1$ can coexist with $b l a_{\mathrm{NDM}-1}$ in $E$. coli, thereby severely worsening such situation ${ }^{5,6}$. Considering the ever-increasing, fast-spreading and highly lethal NDM-1-producing strains, the development of new drugs is urgently needed to combat these pathogens.

The hydrolytic activity of NDM-1 depends on the binding of $\mathrm{Zn}^{2+}$ ions to the active site, which activates nucleophilic $\mathrm{H}_{2} \mathrm{O}$ and causes the cleavage of $\beta$-lactam rings ${ }^{7,8}$. Nevertheless, in the absence of $\mathrm{Zn}^{2+}$ ions, the stability of NDM-1 decreases significantly, which adversely affects the accumulation of this enzyme in the bacterial periplasm ${ }^{9}$. The innate immune system responds to metallo- $\beta$ lactamase-producing bacteria by releasing metal-chelating proteins, which will cause the degradation of metallo- $\beta$-lactamases ${ }^{10,11}$. However, resistant bacteria anchor NDM-1 to the outer membrane $(\mathrm{OM})$ to avoid chelation so that the hydrolytic efficacy can be preserved even under the condition of metal depletion ${ }^{9}$.

Thanatin is an inducible 21-residue insect peptide with a disulfide bond between Cys11 and Cys18 ${ }^{12}$. Our previous studies revealed that thanatin exerts prominent antibacterial effects on extended-spectrum $\beta$-lactamase-producing E. coli ${ }^{13}$. However, whether thanatin is also effective against NDM-1-producing bacteria remains unclear. In the present study, we examined the antibacterial efficacy of thanatin on NDM-1-producing strains and found that it affects both bacterial viability and NDM-1 enzyme activity. Our results showed that thanatin has the property of competitive replacement of divalent cations from bacterial OM, leading to OM disruption. Remarkably, thanatin also acts as an antibiotic adjuvant even under low concentrations by displacing zinc ions from the active site of the NDM-1 enzyme to restore the susceptibility of NDM-1-producing pathogens to $\beta$-lactam antibiotics. The unique antibacterial mechanisms of thanatin provide a strategy for combating infections of NDM-1 pathogens.

\section{Results}

Thanatin exerts bactericidal activity by disrupting $\mathrm{OM}$ integrity. Seven clinically isolated NDM-1-producing strains and three reference strains were used to assess the in vitro antibacterial activity of thanatin. NDM-1 expression was verified in all seven clinically isolated strains (Supplementary Fig. 1). As predicted, thanatin exhibited potent inhibitory effect on the growth of all NDM-1-producing E. coli and K. pneumoniae strains at 0.4-3.2 $\mu \mathrm{M}$ of the minimum inhibitory concentration (MIC) values (Table 1), whereas these strains showed much lower susceptibilities to penicillin, cephalosporin, carbapenem, and quinolone antibiotics (Table 1, Supplementary Tables 1 and 2). The bactericidal kinetics study of thanatin at the MIC levels showed rapid bacterial reduction from $10^{6}$ to $10^{2}$ and less than 50 colonyforming units $(\mathrm{CFU}) / \mathrm{mL}$ at 1 and $3 \mathrm{~h}$, respectively (Fig. 1a, b, Supplementary Fig. 2). The OM integrity was damaged by thanatin in a time-dependent manner, and a distinct increase in the fluorescence intensity was observed $1 \mathrm{~h}$ post incubation (Fig. 1c). The fluorescence intensity of propidium iodide (PI) increased $\sim 2 \mathrm{~h}$ post incubation, indicating an increase in the inner membrane permeability of the bacteria (Fig. 1d). The scanning electron microscopy image showed that the number of $E$. coli cells with dramatic morphological changes gradually increased with increasing thanatin concentration; consequently, the cells exhibited aggravating corrugation on the surface (Fig. 1e).

Thanatin damages the OM by promoting the release of divalent cations. Divalent cations, which link the negatively charged phosphate groups between lipopolysaccharides (LPS) molecules via ionic bridges, are crucial for the OM integrity of Gramnegative bacteria ${ }^{14}$. The replacement or chelation of divalent cations would disrupt OM integrity and permeabilize bacteria. The release of $\mathrm{Ca}^{2+}$ and LPS was detected to further investigate the effects of thanatin on the OMs of NDM-1-producing bacteria. NDM-1-producing E. coli XJ141026 showed an immediate release of $\mathrm{Ca}^{2+}$ into the supernatant after incubation with thanatin at concentrations of 13 or $26 \mu \mathrm{M}$ as early as $0.5 \mathrm{~h}$ post incubation (Fig. 2a). Thereafter, LPS was released at $3 \mathrm{~h}$, indicating the gradual destruction of OM under the condition of divalent cation loss (Fig. 2b). Consistently, the bacterial loads of the thanatintreated groups significantly decreased $3 \mathrm{~h}$ post incubation (Fig. 2c).

We then determined the release of $\mathrm{Ca}^{2+}$ and LPS induced by thanatin from bacterial $\mathrm{OM}$ in a mouse pneumonia model infected with NDM-1-producing E. coli XJ141026 or $K$. pneumoniae XJ155017. The results showed that the LPS concentration in bronchoalveolar lavage fluid (BALF) increased

Table 1 MICs of thanatin and antibiotics in seven NDM-1-producing strains

\begin{tabular}{|c|c|c|c|c|c|c|c|}
\hline \multirow[t]{2}{*}{ Strains } & \multicolumn{7}{|l|}{ MICs } \\
\hline & $\begin{array}{l}\text { Thanatin } \\
(\mu \mathrm{g} / \mathrm{mL}) /(\mu \mathrm{M})\end{array}$ & $\begin{array}{l}\text { Piperacillin } \\
(\mu \mathrm{g} / \mathrm{mL})\end{array}$ & $\begin{array}{l}\text { Oxacillin } \\
(\mu \mathrm{g} / \mathrm{mL})\end{array}$ & $\begin{array}{l}\text { Meropenem } \\
(\mu \mathrm{g} / \mathrm{mL})\end{array}$ & $\begin{array}{l}\text { Imipenem } \\
(\mu \mathrm{g} / \mathrm{mL})\end{array}$ & $\begin{array}{l}\text { Ceftazidime } \\
(\mu \mathrm{g} / \mathrm{mL})\end{array}$ & $\begin{array}{l}\text { Cefotaxime } \\
(\mu \mathrm{g} / \mathrm{mL})\end{array}$ \\
\hline E. coli ATCC25922 & $4 / 1.6$ & 2 & 64 & $<0.125$ & $<0.125$ & $<0.125$ & $<0.125$ \\
\hline E. coli ATCC 35218 & $1 / 0.4$ & $>256$ & 256 & $<0.125$ & $<0.125$ & $<0.125$ & $<0.125$ \\
\hline K. pneumoniae ATCC13883 & $4 / 1.6$ & 8 & 64 & $<0.125$ & $<0.125$ & $<0.125$ & $<0.125$ \\
\hline NDM-1 E. coli XJ141015 & $2 / 0.8$ & $>256$ & $>256$ & 64 & 16 & $>256$ & $>256$ \\
\hline NDM-1 E. coli XJ141026 & $2 / 0.8$ & $>256$ & $>256$ & 64 & 16 & $>256$ & $>256$ \\
\hline NDM-1 E. coli XJ141047 & $2 / 0.8$ & $>256$ & $>256$ & 64 & 32 & $>256$ & $>256$ \\
\hline $\begin{array}{l}\text { NDM-1 K. pneumoniae } \\
\text { XJ155017 }\end{array}$ & $8 / 3.2$ & $>256$ & $>256$ & $>256$ & $>256$ & $>256$ & $>256$ \\
\hline $\begin{array}{l}\text { NDM-1 K. pneumoniae } \\
\text { XJ155018 }\end{array}$ & $8 / 3.2$ & $>256$ & $>256$ & 128 & 32 & $>256$ & $>256$ \\
\hline $\begin{array}{l}\text { NDM-1 K. pneumoniae } \\
\text { XJ155019 }\end{array}$ & $8 / 3.2$ & $>256$ & $>256$ & 128 & 128 & $>256$ & $>256$ \\
\hline $\begin{array}{l}\text { NDM-1 K. pneumoniae } \\
\text { XJ155020 }\end{array}$ & $8 / 3.2$ & $>256$ & $>256$ & 128 & 128 & $>256$ & $>256$ \\
\hline
\end{tabular}


a

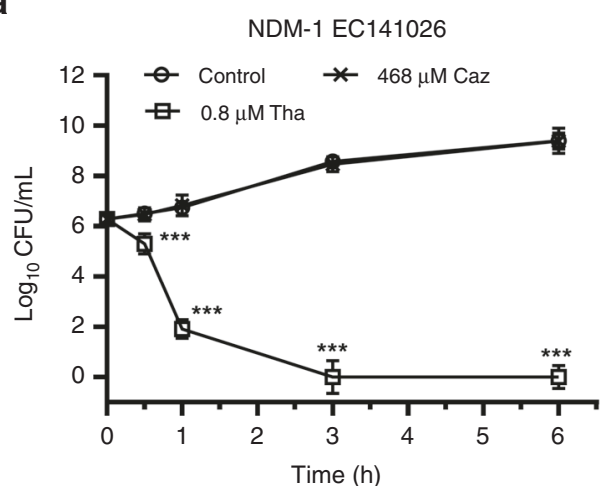

C

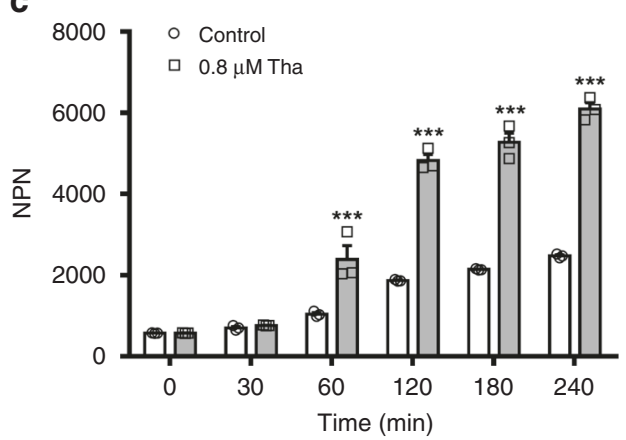

e

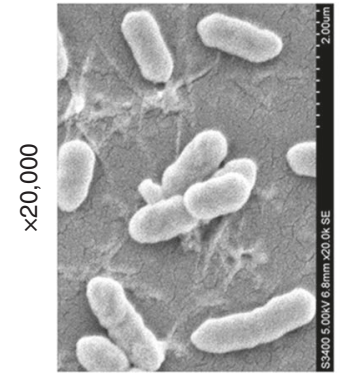

Control

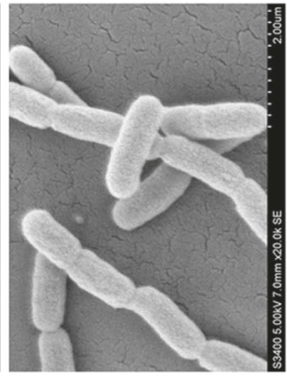

0.8 b

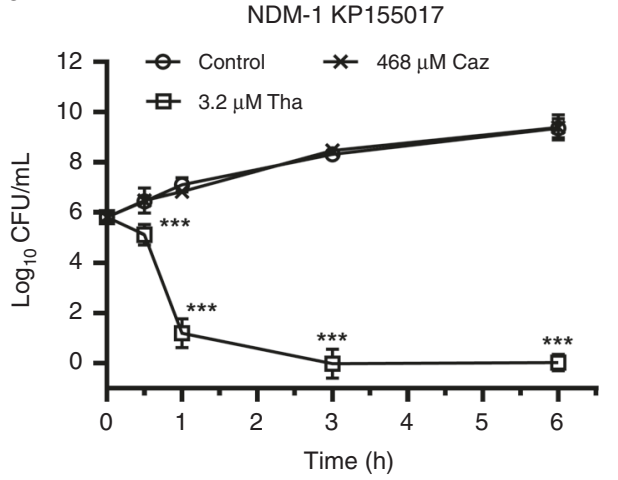

d
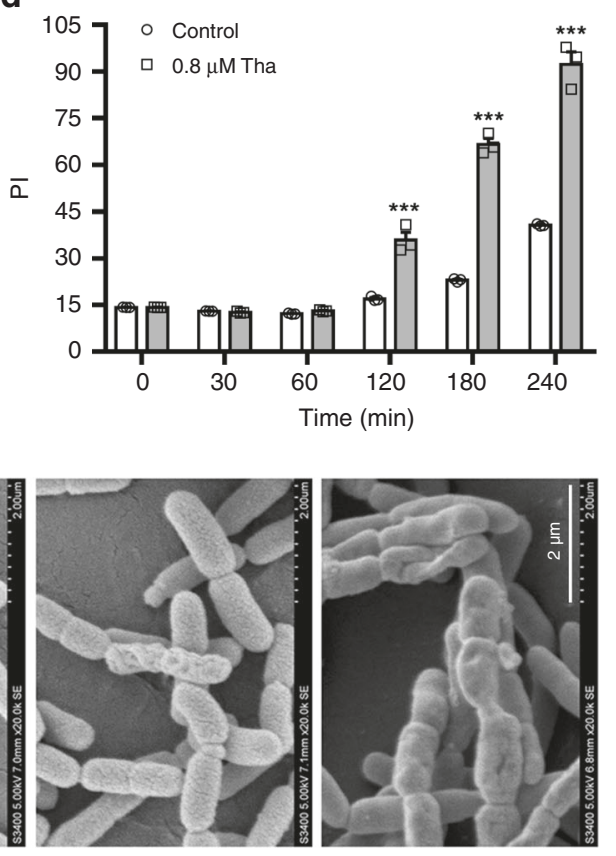

1.6

Tha $(\mu \mathrm{M})$

Fig. 1 Thanatin disrupts the integrity of bacterial membrane. a, b Kill curves of thanatin (Tha) and ceftazidime (Caz) against NDM-1-producing E. coli XJ141026 (a) and K. pneumoniae XJ155017 (b). Cell numbers were determined by plating for colony counts. c, d Outer and inner membrane permeabilization of thanatin was measured by detecting the fluorescence intensity of NPN (c) and PI (d) in E. coli XJ141026. e Morphology of E. coli XJ141026 was investigated by scanning electron microscopy at $4 \mathrm{~h}$ after thanatin treatment. Scale bar $=2 \mu \mathrm{m}$. All data are shown as the mean \pm s.e.m. from three independent experiments. P-values were determined by two-way ANOVA; ${ }^{\star \star \star} P<0.001$ vs. control. Source data are provided in Source Data file

significantly after treatment with thanatin for $1 \mathrm{~h}$, whereas no significant difference was observed at $6 \mathrm{~h}$ (Fig. 2d, Supplementary Fig. 3a). The lack of increase in LPS release in BALF at $6 \mathrm{~h}$ may be associated with the decrease in the bacterial titers after thanatin treatment (Fig. 2e, Supplementary Fig. 3b). The survival rates were improved from 40 to $90 \%$ after treatment with $6 \mathrm{mg} / \mathrm{kg}$ thanatin in E. coli XJ141026-infected mice (Fig. 2f) and from 50 to $100 \%$ after treatment with $9 \mathrm{mg} / \mathrm{kg}$ thanatin in $\mathrm{K}$. pneumoniaeinfected mice (Supplementary Fig. 3c). The increasing survival rates caused by thanatin treatment were associated with reduced bacterial titers and restricted pneumonia aggravation in the lungs of the infected mice (Supplementary Figs. 3d, e and Supplementary Figs. 4a, b).

Thanatin competitively replaces divalent cations from LPS. To verify the mechanism of thanatin in promoting the release of LPS and $\mathrm{Ca}^{2+}$, we investigated the relationship among divalent cations, LPS, and antibacterial activity of thanatin. Our results showed that thanatin-induced LPS release from NDM-1producing E. coli XJ141026 was significantly reduced with increasing $\mathrm{Ca}^{2+}$ concentrations (Fig. 3a). Meanwhile, the bactericidal efficacy of thanatin was inhibited by adding extra divalent ions into the systems (Fig. 3b). The MICs increased dramatically with increasing concentrations of $\mathrm{Ca}^{2+}$ and $\mathrm{Mg}^{2+}$ (Fig. 3c). Consistently, the chelation of the divalent cations by metal-chelating agent dipicolinic acid (DPA) and ethylenediaminetetraacetic acid (EDTA) facilitated the bactericidal activity of thanatin, that is, the MICs were decreased to 0.0625 - and 0.1563 fold compared with that when thanatin alone was used (Fig. 3d). These results indicated that thanatin likely competitively replaces the divalent cations from OM to exert antibacterial activity. To acquire direct evidence, we examined the affinities of thanatin, $\mathrm{Ca}^{2+}$, and $\mathrm{Mg}^{2+}$ to LPS by isothermal titration calorimetry (ITC). The equilibrium dissociation constant $\left(K_{\mathrm{d}}\right)$ of thanatin to LPS was $1.09 \pm 0.11 \mu \mathrm{M}$, whereas the values for $\mathrm{Ca}^{2+}$ and $\mathrm{Mg}^{2+}$ were 

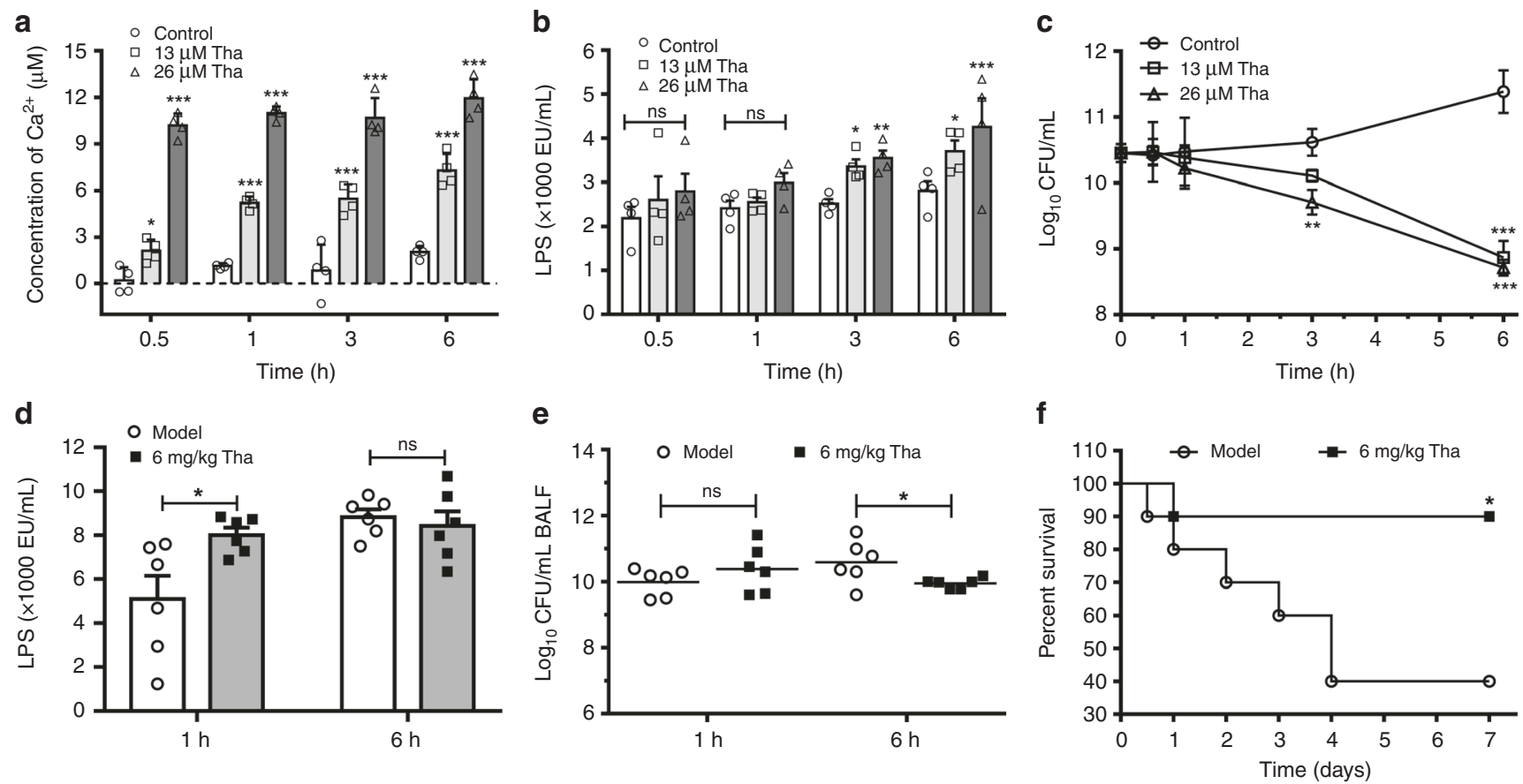

Fig. 2 Thanatin promotes the release of $\mathrm{Ca}^{2+}$ and LPS from the OM. a-c Release of $\mathrm{Ca}^{2+}$ (a) and LPS (b) from thanatin-treated $E$. coli XJ141026 (3 $\times 10^{10}$ $\mathrm{CFU} / \mathrm{mL}$ ) was detected, and time-kill curves were monitored (c). d, e LPS levels (d) and bacterial loads (e) in the BALF of E. coli XJ141026-infected pneumonia mice were analyzed at 1 and $6 \mathrm{~h}$ after $6 \mathrm{mg} / \mathrm{kg}$ thanatin treatment ( $n=6$ per group). $\mathbf{f}$ Survival curves for the $E$. coli XJ141026 pneumonia model. BALB/c mice were intranasally infected with a sublethal dose of $E$. coli XJ141026 and treated with $6 \mathrm{mg} / \mathrm{kg}$ thanatin via intraperitoneal injection $(n=10$ per group). All data are shown as the mean \pm s.e.m. from at least three independent experiments. $P$-values were determined by two-way ANOVA (a-c), two-tailed unpaired $t$-test $(\mathbf{d}, \mathbf{e})$ or log-rank test $(\mathbf{f})$. ns means not significant; ${ }^{\star} P<0.05,{ }^{\star \star} P<0.01,{ }^{\star \star \star} P<0.001$ vs. control or model. Source data are provided in Source Data file

a

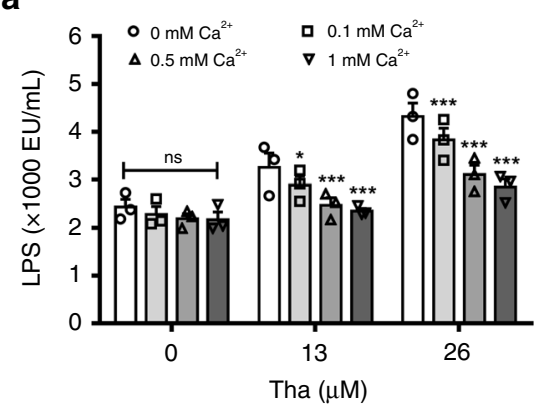

C

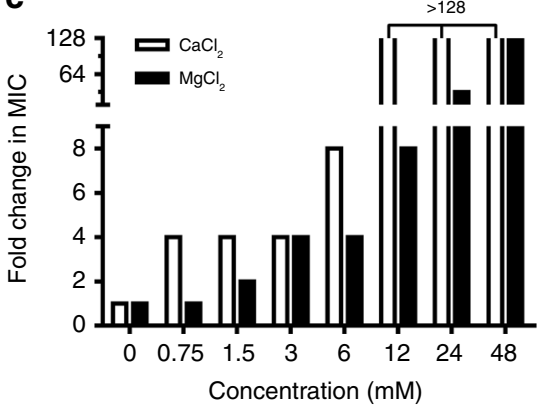

b

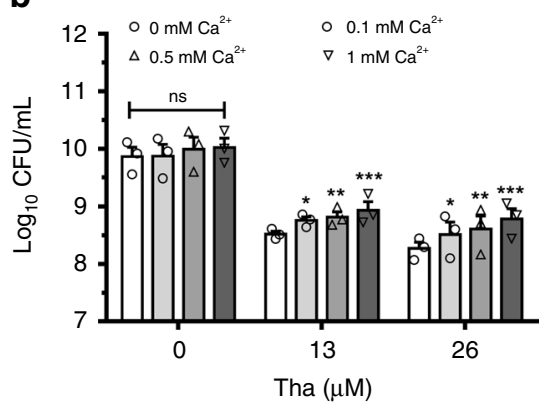

d

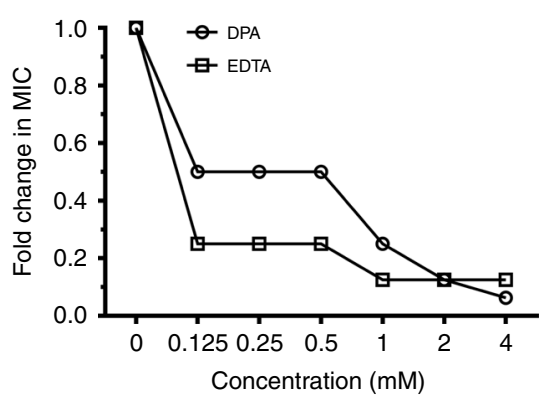

e

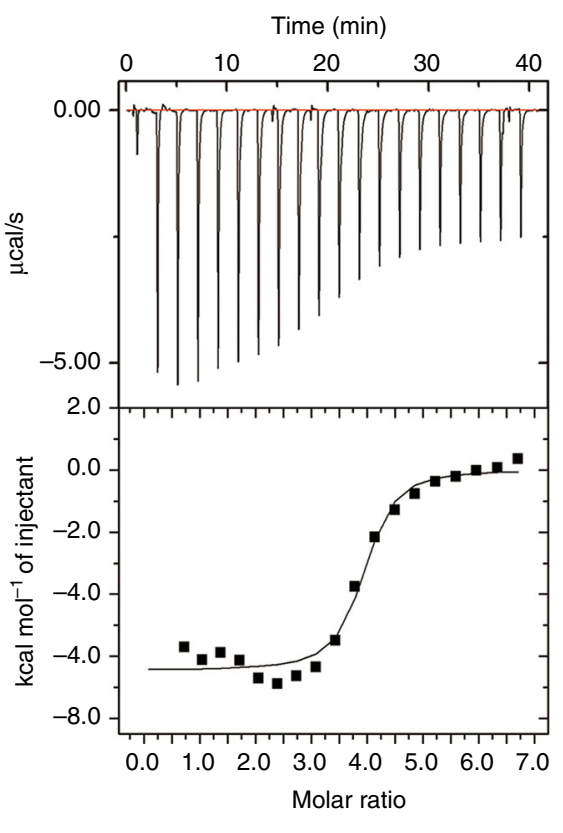

Fig. 3 Thanatin replaces divalent cations from LPS. a, b Effects of $\mathrm{Ca}^{2+}$ on thanatin-induced LPS release from NDM-1-producing E. coli XJ141026 (a) and CFUs (b) after treatment with 13 or $26 \mu \mathrm{M}$ thanatin. $\mathbf{c}$, d Effect of the divalent cations $\mathrm{Ca}^{2+}$ or $\mathrm{Mg}^{2+}$ (c) or the metal-chelating agents DPA or EDTA (d) on the MIC of thanatin against NDM-1-producing E. coli XJ141026. e ITC thermograms for the binding of LPS to thanatin. The downward peaks indicate an exothermic process. All data are shown as the mean \pm s.e.m. from three independent experiments. $P$-values were determined by two-way ANOVA (a, b). ns means not significant; ${ }^{\star} P<0.05,{ }^{\star} P<0.01,{ }^{\star \star}{ }^{\star} P<0.001$ vs. control $\left(0 \mathrm{mM} \mathrm{Ca}{ }^{2+}\right)$. Source data are provided in Source Data file 

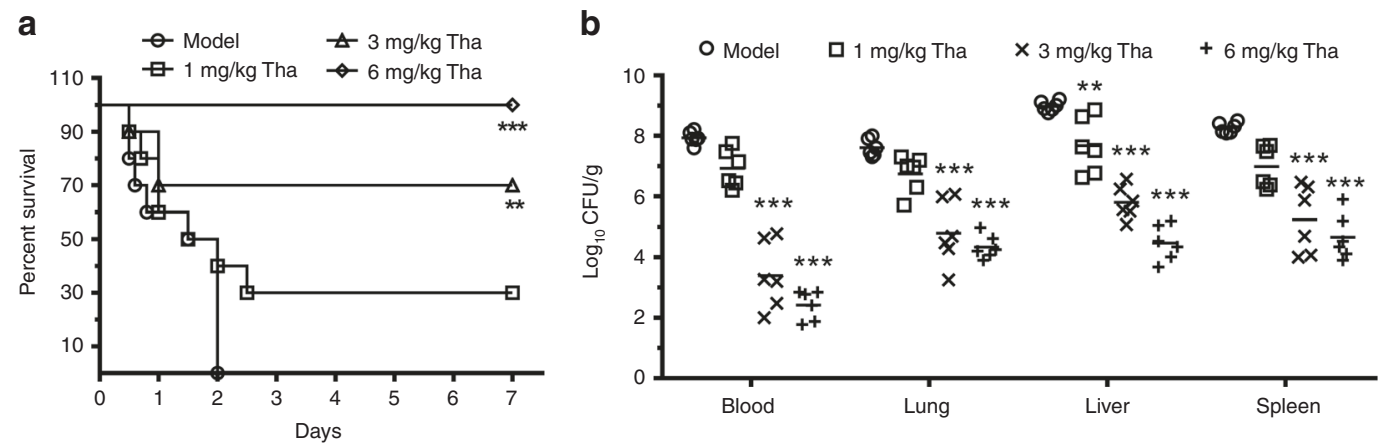

Fig. 4 Thanatin protects NDM-1-producing E. coli-infected mice. a Survival curves for the E. coli XJ141026 sepsis model. BALB/c mice were intraperitoneally administered with a lethal dose of $E$. coli XJ141026 and treated with three doses of thanatin via intraperitoneal injection ( $n=10$ per group). b Bacterial loads in the blood, lungs, livers, and spleens of thanatin-treated $E$. coli XJ141026-infected mice were determined $24 \mathrm{~h}$ after infection ( $n=6 \mathrm{per}$ group). $P$-values were determined by log-rank test (a) or one-way ANOVA with post-Bonferroni's comparison test $(\mathbf{b}) .{ }^{\star \star} P<0.01,{ }^{\star \star \star} P<0.001$ vs. model. Source data are provided in Source Data file

much higher, indicating the stronger affinity of thanatin than that of $\mathrm{Ca}^{2+}$ or $\mathrm{Mg}^{2+}$ to LPS (Fig. 3e, Supplementary Fig. 5 and Supplementary Table 3). All these data suggested that thanatin competitively replaces the divalent cations to bind to LPS, thereby disrupting the integrity of $\mathrm{OM}$ and leading to bacterial death.

Thanatin protects mice infected with NDM-1-producing $E$. coli. We examined the in vivo therapeutic effects of thanatin in a sepsis model induced by NDM-1-producing E. coli XJ141026. All septic mice died within $2 \mathrm{~d}$ post infection, whereas treatment with 1,3 , and $6 \mathrm{mg} / \mathrm{kg}$ thanatin markedly increased the survival rate from 0 to $30 \%, 70 \%$, and $100 \%$, respectively (Fig. 4a). Tissues were collected $24 \mathrm{~h}$ post infection to analyze bacterial CFUs after treatment. The results showed that the bacterial titers decreased with increasing thanatin dose (Fig. 4b). The therapeutic effects were confirmed by histological staining. We observed dramatic pathological changes in the model group, including large amounts of inflammatory cell infiltration, alveolar fusion, congestion in the spleen red pulp area, hepatic sinusoidal dilation and congestion (Supplementary Fig. 6). By contrast, the thanatin treatment rescued the pathological damages in a dose-dependent manner (Supplementary Fig. 6).

To examine the cell toxicity of thanatin, we used human umbilical vein endothelial cells (HUVECs), human pulmonary alveolar epithelial cells (HPAEpiCs), and mouse neuron cells. At the concentration of $200 \mu \mathrm{M}$, almost all thanatin-treated HPAEpiCs were alive, but only $73.8 \%$ of cells survived after colistin treatment (Supplementary Fig. 7a). Similarly, $82.9 \%$ of thanatin-treated HUVECs survived, but $60.5 \%$ of colistin-treated cells were alive at the same concentration of $200 \mu \mathrm{M}$ (Supplementary Fig. 7b). These results indicated that thanatin had lower toxicity toward HPAEpiCs and HUVECs than colistin. Hoechst 33342 and PI staining assay results showed that no differences between the control and $50 \mu \mathrm{M}$ thanatin-treated groups when incubated with mouse primary neuron cells (Supplementary Fig. 7c). This finding implied that thanatin exhibited high selectivity toward bacterial cell walls but not on mammalian cell membranes.

Thanatin inactivates NDM-1 by displacing zinc ions. The NDM-1 protein is anchored to the OM of Gram-negative bacteria and is involved in enzymatic reaction in the periplasmic space ${ }^{9}$. Both thanatin and colistin damage the OM integrity, causing the release of NDM-1 into the solution in a time- and concentrationdependent manner (Fig. 5a, Supplementary Figs. 8a, b and 13).
Meanwhile, the levels of NDM-1 decreased in the thanatin- and colistin-treated E. coli XJ141026 cell precipitates (Supplementary Figs. $8 \mathrm{~b}, \mathrm{c}$ and 13). As a result, the hydrolysis rates of the precipitates consistently decreased with increasing thanatin or colistin concentration due to the release of NDM-1 into the supernatant (Supplementary Figs. 8d, e). We speculated that high NDM-1 levels in the supernatant were related to the efficient hydrolytic activity. Unexpectedly, the hydrolysis of the supernatant to imipenem decreased with increasing thanatin concentration (Fig. 5b). By contrast, treatment with high colistin concentration led to strong hydrolytic activity to imipenem (Supplementary Fig. 8f).

In addition to membrane permeabilization, thanatin likely interacted with NDM-1 and inhibited its hydrolytic activity. To determine the direct interaction between NDM-1 and thanatin, microscale thermophoresis (MST) was used to detect the binding affinities of apo-NDM-1 to $\mathrm{Zn}^{2+}$, thanatin and colistin. We measured a $K_{\mathrm{d}}$ of $\sim 0.71 \pm 0.06 \mu \mathrm{M}$ for the interaction between NDM-1 and thanatin (Fig. 5c). Weak affinities to NDM-1 were detected with $K_{\mathrm{d}}$ values of $7.36 \pm 0.45 \mu \mathrm{M}$ for $\mathrm{Zn}^{2+}$ and $61.68 \pm$ $4.92 \mu \mathrm{M}$ for colistin (Supplementary Figs. 9a, b). These results suggested that thanatin exhibited approximately 10 times higher affinity to NDM-1 than $\mathrm{Zn}^{2+}$.

To further define whether thanatin can inhibit the enzymatic activity of NDM-1, we incubated the purified NDM-1 protein with gradient concentrations of thanatin, and examined the hydrolytic efficacy. The results showed that thanatin inhibited NDM-1 activity in a concentration-dependent manner, with the half-maximum inhibitory concentration $\left(\mathrm{IC}_{50}\right)$ value of $3.21 \pm$ $0.78 \mu \mathrm{M}$ (Fig. $5 \mathrm{~d}$ ). Classical kinetic plots with varied substrate and inhibitor concentrations were determined to show the manner by which thanatin inhibited NDM-1. The relevant Lineweaver-Burk plot proved that thanatin was a competitive inhibitor for NDM-1, with the inhibition constant $\left(K_{\mathrm{i}}\right)$ value of $2.84 \pm 0.33 \mu \mathrm{M}$ (Fig. $5 \mathrm{e}$, Supplementary Fig. 10). The kinetic parameters are shown in Supplementary Table 4 . These results suggested that thanatin could directly inhibit enzymatic activity of NDM-1 as a competitive inhibitor.

NDM-1 is a dizinc hydrolase with two $\mathrm{Zn}^{2+}$ ions in its active site $^{15,16}$. To directly confirm whether thanatin inhibits NDM-1 by removing $\mathrm{Zn}^{2+}$ from NDM-1, we used inductively coupled plasma-mass spectrometry (ICP-MS) to measure the zinc content in holo-NDM-1 after thanatin treatment. The results confirmed that $2.23 \pm 0.28$ molar equivalents of zinc were bound to holoNDM-1 (Fig. 5f). However, only $1.03 \pm 0.25$ molar equivalents of zinc remain bound to NDM-1 after thanatin treatment (Fig. 5f). 
a

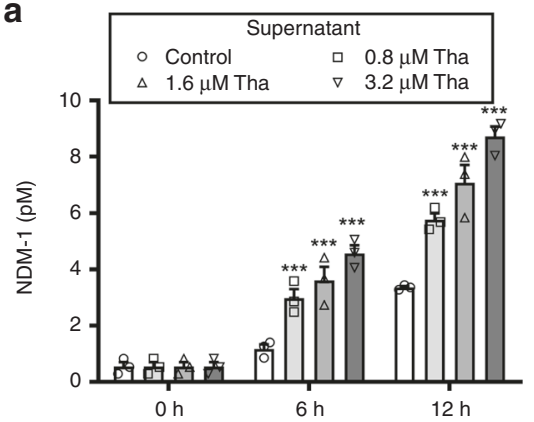

d

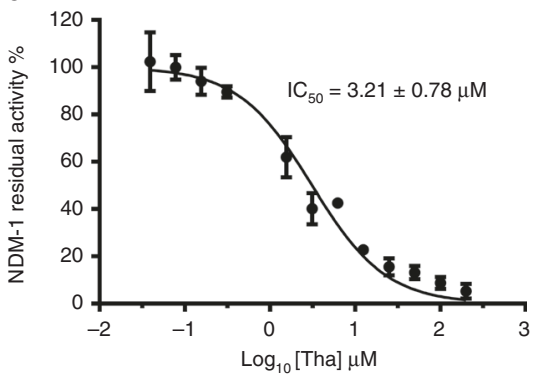

b

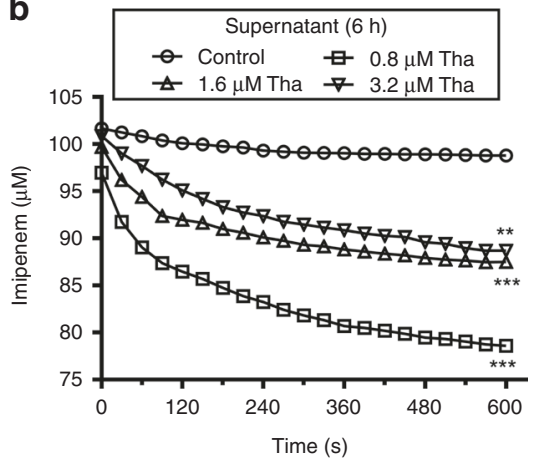

e

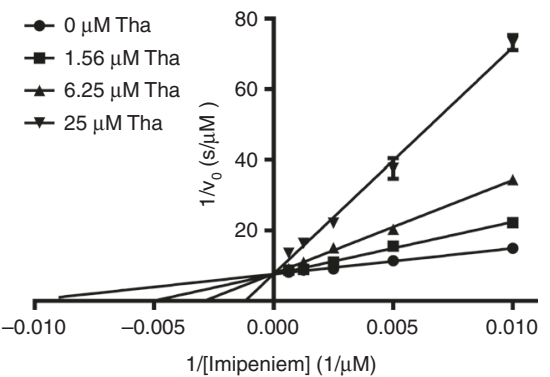

C

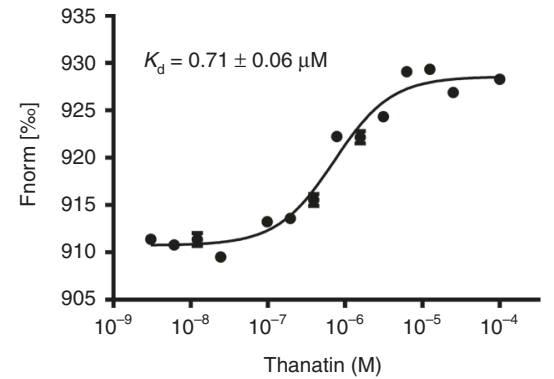

f

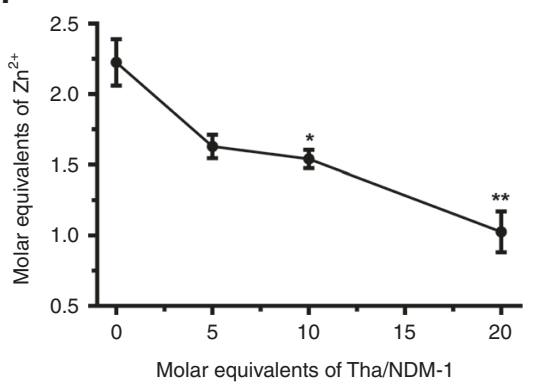

Fig. 5 Thanatin inactivates NDM-1. a Thanatin induced NDM-1 release to $E$. coli culture supernatant. $\mathbf{b}$ Hydrolytic effects of the supernatant on imipenem. The supernatant was obtained from thanatin-treated NDM-1-producing E. coli XJ141026 at $6 \mathrm{~h}$. c $K_{\mathrm{d}}$ value for binding of thanatin to RED-tris-NTA-labeled apo-NDM-1 was obtained by MST assay. $\mathbf{d}$ Thanatin inhibited the activity of NDM-1. $\mathbf{e}$ The Lineweaver-Burk plot. Thanatin is a competitive inhibitor of NDM-1. f Molar equivalents of zinc in holo-NDM-1 were detected by ICP-MS after thanatin treatment. Data are shown as the mean \pm s.e.m. from three independent experiments. P-values were determined by two-way ANOVA $(\mathbf{a}, \mathbf{b})$, or one-way ANOVA with Bonferroni's comparison test $(\mathbf{f})$. ${ }^{\star} P<0.05$ ${ }^{\star \star} P<0.01,{ }^{\star \star \star} P<0.001$ vs. control. Source data are provided in Source Data file

Hence, thanatin released $\sim 1.2$ molar equivalents of zinc from holo-NDM-1. In addition, NDM-1 activity inhibited by thanatin was gradually rescued with increasing $\mathrm{Zn}^{2+}$ concentrations (Supplementary Fig. 11). Hence, thanatin inhibited NDM-1 reversibly by removing $\mathrm{Zn}^{2+}$ from NDM-1. Thanatin, as a cationic peptide, bears a significant positive charge $(+6)$ at physiological $\mathrm{pH}^{12}$, implying a repulsive force against metal ions. Although cysteine residues can bind to $\mathrm{Zn}^{2+17}$, the two cysteines in thanatin have formed a disulfide bridge and cannot function as metal-chelating residues. Therefore, thanatin likely inactivated NDM-1 by displacing the $\mathrm{Zn}^{2+}$ ions, rather than by exerting a chelating effect. All the data showed that thanatin inactivated NDM-1 by displacing $\mathrm{Zn}^{2+}$ as a competitive inhibitor.

Thanatin reverses carbapenem resistance in vivo. The capacity of NDM-1 inhibition suggested that thanatin could potentially protect conventional antibiotics from hydrolysis and restore the antibiotic susceptibility of NDM-1-producing strains. The results of the checkerboard assay showed that, in the presence of subMIC thanatin, the antibacterial activity of meropenem toward NDM-1-producing E. coli XJ141026 was markedly restored, with the MIC value decreased from $144 \mu \mathrm{M}$ to $18 \mu \mathrm{M}$ (Fig. 6a). All fractional inhibitory concentration (FIC) indices were $\leq 1$ for the seven NDM-1-producing strains, indicating that thanatin exerted synergistic or additive effects with imipenem and meropenem (Table 2). The combination of meropenem/imipenem and thanatin showed great bactericidal capacities against NDM-1producing E. coli XJ141026 at concentrations much lower than MICs when monoadministered (Fig. 6b, c). The effects of the combination treatment were determined with the six other NDM1 -producing strains. Consistent results were obtained, indicating that thanatin overcame the antibiotic resistance by inhibiting the hydrolytic activity of NDM-1 (Supplementary Fig. 12). In the systemic infection model, the combination of meropenem and thanatin enhanced the survival rates from $0 \%$ for the $0.1 \mathrm{mg} / \mathrm{kg}$ thanatin monotherapy group and $30 \%$ for the $10 \mathrm{mg} / \mathrm{kg}$ meropenem monotherapy group to $79 \%$ (Fig. 6d). Bacterial titer data showed that the combination of meropenem and thanatin efficiently restricted the development of sepsis, and the CFUs in the spleen and liver were significantly reduced compared with any other monotherapy groups (Fig. 6e, f).

\section{Discussion}

Efficient antibiotic treatment must be developed for serious infections caused by NDM-1-producing super-resistant bacteria. Current therapeutic strategies by using polymyxins and tigecycline are problematic due to their high toxicity, poor tissue penetrability, and undesirable pharmacokinetic properties ${ }^{18-20}$. Recent studies have reported that several compounds exert potent activities against NDM-1-producing bacteria ${ }^{21,22}$. However, the situation of restraining infections caused by NDM-1-producing strains is still severe, given high resistance to almost all $\beta$-lactam antibiotics, especially carbapenems. Here, we propose thanatin as a promising agent to combat NDM-1-producing bacteria by permeabilization and NDM-1 enzyme inactivation. Thanatin may be potentially used as a therapeutic strategy.

Divalent cations $\left(\mathrm{Mg}^{2+}\right.$ and $\left.\mathrm{Ca}^{2+}\right)$ are essential to bridge negative-charged phosphate groups between the LPS molecules, avoiding the accumulation of repulsive forces and maintaining the stability of the bacterial $\mathrm{OM}^{14}$. Our results indicated that thanatin causes the release of $\mathrm{Ca}^{2+}$ and LPS in a concentrationdependent manner (Fig. 2a, b). The same phenomenon was also observed in vivo, that is, the LPS levels in BALF significantly increased in the mouse pneumonitis model after thanatin 
a
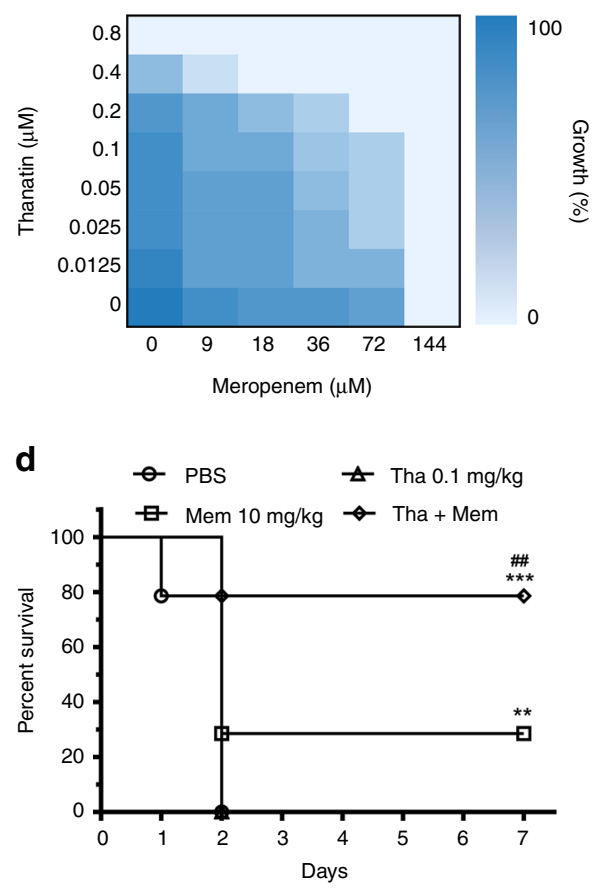

b

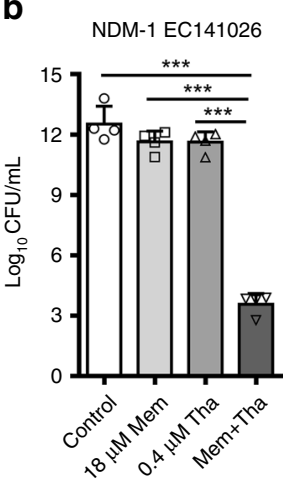

e

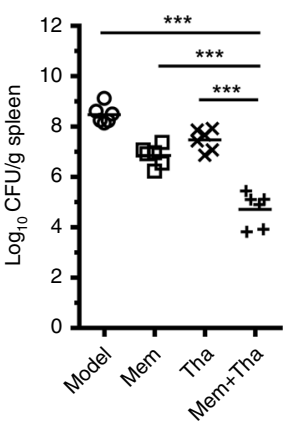

C

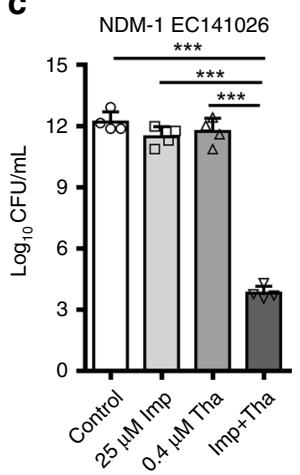

f

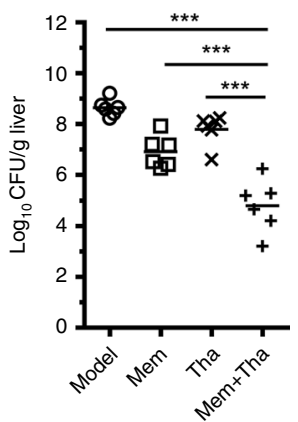

Fig. 6 Thanatin rescues the activity of carbapenem. a Microdilution checkerboard analysis showing the combined effect of thanatin (Tha) and meropenem (Mem) against NDM-1-producing E. coli XJ141026. The heat plot showed an average of three technical replicates. b, c Sub-MICs of thanatin reversed the activity of meropenem (b) and imipenem (Imp) (c) resistance in vitro. d NDM-1-producing E. coli XJ141026-infected mice were treated with a single dose of meropenem $(10 \mathrm{mg} / \mathrm{kg})$, a combination of meropenem $(10 \mathrm{mg} / \mathrm{kg})$ and thanatin $(0.1 \mathrm{mg} / \mathrm{kg})$, thanatin alone $(0.1 \mathrm{mg} / \mathrm{kg})$, or PBS via intraperitoneal injection ( $n=14$ per group). e, $\mathbf{f}$ Bacterial loads in the spleen (e) and liver (f) of thanatin-treated E. coli XJ141026-infected mice were determined by plating the samples for colony counts $24 \mathrm{~h}$ after treatment ( $n=6$ per group). Data are shown as the mean \pm s.e.m. from at least three independent experiments. $P$-values were determined by one-way ANOVA with Bonferroni's comparison test $(\mathbf{b}, \mathbf{c}, \mathbf{e}, \mathbf{f})$, or by log-rank test $(\mathbf{d}) .{ }^{\star \star} P<0.01,{ }^{\star \star \star} P<0.001$; ${ }^{\# \# P<0.01}$ between $10 \mathrm{mg} / \mathrm{kg}$ Mem and Tha + Mem. Source data are provided in Source Data file

\begin{tabular}{|lll|}
\hline Table 2 FIC indices against NDM-1 clinical isolates \\
Strains & \multicolumn{2}{l}{ FIC Index } \\
\cline { 2 - 3 } & Mem + Tha & Imp + Tha \\
\hline NDM-1 E. coli XJ141015 & 0.625 & 1 \\
NDM-1 E. coli XJ141026 & 0.625 & 1 \\
NDM-1 E. coli XJ141047 & 0.508 & 0.531 \\
NDM-1 K. pneumoniae XJ155017 & 0.750 & 0.750 \\
NDM-1 K. pneumoniae XJ155018 & 0.563 & 1 \\
NDM-1 K. pneumoniae XJ155019 & 0.516 & 0.313 \\
NDM-1 K. pneumoniae XJ155020 & 0.508 & 0.375 \\
\hline
\end{tabular}

Tha thanatin, Mem meropenem, Imp imipenem

treatment for $1 \mathrm{~h}$ (Fig. 2d, Supplementary Fig. 3a). These effects can be significantly inhibited by increasing the concentrations of divalent cations; as a result, the antibacterial efficacy of thanatin was adversely affected (Fig. 3). The affinity of thanatin is much higher than that of $\mathrm{Ca}^{2+}$ or $\mathrm{Mg}^{2+}$ to LPS (Fig. 3e, Supplementary Fig. 5), suggesting that thanatin competitively replaces the divalent cations from $\mathrm{OM}$ and kills Gram-negative bacteria by permeabilization. Sinha et al. ${ }^{23}$ found that thanatin forms an antiparallel $\beta$-sheet structure with the LPS micelle through solution nuclear magnetic resonance; such structure, increases the hydrophobicity and cationicity of thanatin to LPS. These findings provide evidence to support the hypothesis that thanatin plays an antibacterial role by replacing divalent cations. Vetterli et al. ${ }^{24}$ reported that thanatin targets LptA and LptD in the network of periplasmic protein-protein interactions, leading to the inhibition of LPS transport and OM biogenesis in E. coli. However, they proposed that thanatin has no membrane-permeabilizing effect, which contradicts the present results. We consider that the distinct data raised by Vetterli et al. may be due to the high concentrations of $\mathrm{Ca}^{2+}(1 \mathrm{mM})$ and $\mathrm{Mg}^{2+}(0.5 \mathrm{mM})$ used in the membrane permeabilization assays. According to our results, the antibacterial activity of thanatin obviously decreased under the effect of $1 \mathrm{mM} \mathrm{Ca}^{2+}$; that is, the MIC of thanatin against NDM-1producing E. coli XJ141026 increased four times (Fig. 3c).

NDM-1 inhibitors, which antagonize multiple subtypes of metallo- $\beta$-lactamases and protect $\beta$-lactam antibiotics from being hydrolyzed, have been widely studied for synergistic application with $\beta$-lactam antibiotics to restore their bactericidal effects $^{15,25,26}$. The most common mechanism of metallo- $\beta$ lactamase inhibitors is metal ion binding 27 . A recent study showed that the naturally occurring fungal compound aspergillomarasmine A inhibits the NDM-1 protease activity by chelating zinc ions from the active site ${ }^{28}$. Distinct from the direct metal ion binding, our results demonstrated that thanatin acts as an NDM1 inhibitor by competitively displacing zinc ions. This effect was only observed in thanatin; whereas colistin exhibited almost no effect on NDM-1 activity, indicating that not all cationic antimicrobial peptides can affect enzymolysis (Fig. 5, Supplementary Figs. 8 and 13). This property indicates that thanatin can be used as an NDM-1 inhibitor to effectively restore the susceptibility of NDM-1-producing bacteria to conventional antibiotics (Fig. 7). 

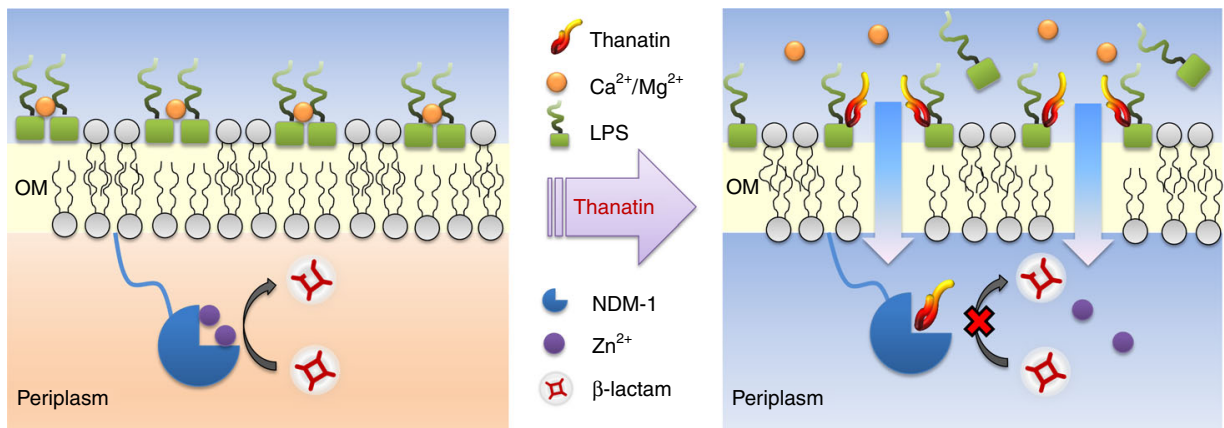

Fig. 7 Mechanism of action of thanatin. Thanatin disrupts outer membrane integrity and overcomes metallo- $\beta$-lactamase-mediated antibiotic resistance by competitively displacing divalent cations

The survival of eukaryotes (HUVECs, HPAEpiCs, and mouse neuron cells) was barely affected after incubation with $100 \mu \mathrm{M}$ thanatin (Supplementary Fig. 7), which is much higher than the antibacterial concentration of thanatin $(\mathrm{MIC}=0.4-3.2 \mu \mathrm{M})$. Compared with the broadly used polypeptide antibiotic colistin, thanatin exhibits not only excellent antibacterial efficacy but also low cytotoxicity. As such, thanatin is a safe antibacterial agent when applied in vivo and has the potential to combat infections caused by NDM-1-producing bacteria.

In summary, we propose that the antibacterial activity of thanatin is due to dual effects on both the bacterial $\mathrm{OM}$ and the NDM-1 enzyme. Thanatin kills NDM-1-producing bacteria and efficiently increases the survival rate of infected mice without conferring obvious toxicity. As such, thanatin is a promising candidate to combat the emergence and dissemination of NDM1 -producing bacteria.

\footnotetext{
Methods

Bacterial strains. E. coli ATCC25922, E. coli ATCC35218, and K. pneumonia ATCC13883 were used as references based on the Chinese National Center for Surveillance of Antimicrobial Resistance. The clinical isolates of E. coli XJ141015, E. coli XJ141026, E. coli XJ141047, K. pneumonia XJ155017, K. pneumonia XJ155018, K. pneumonia XJ155019, and K. pneumonia XJ155020 were obtained from the clinical laboratory of Xijing Hospital (Xi'an, China).
}

Screening and identification of NDM-1-producing strains. Clinical isolate strains were identified and screened by the Phoenix 100 automated bacterial identification system to rapidly detect antimicrobial resistance. Total DNA was extracted by the TIANamp Bacteria DNA Kit according to the manufacturer's protocol. The presence of $b l a_{\mathrm{NDM}-1}$ was confirmed using a diagnostic kit for NDM1 (Puruikang Bio Inc., Shenzhen, China) based on fluorescent quantitative polymerase chain reaction assay. According to the instruction, Ct values of less than 37 were considered positive.

Synthesis of thanatin. Thanatin (GSKKPVPIIYCNRRTGKCQRM) was synthesized by the solid-phase method applying Fmoc (9-fluorenylmethyloxycarbonyl) active ester chemistry ${ }^{12,29}$. The crude peptide was purified to over $98 \%$ chromatographic homogeneity by reverse-phase high-performance liquid chromatography and confirmed by mass spectrometry analysis.

Expression and purification of NDM-1. The $b l a_{\mathrm{NDM}-1}$ gene was synthesized by Integrated DNA Technologies (Detai Bio-Tech Co., Ltd., Nanjing, China) by deleting the signal peptide gene sequence and introducing a $6 \times$ His gene sequence at the $5^{\prime}$-site. The gene was then cloned into pET30a digested with NdeI and HindIII. The vector was used to encode the NDM-1 enzyme fused to the aminoterminal histidine tag (MHHHHHHMPGEIRPTIGQQMETGDQRFGDLVFRQ LAPNVWQHTSYLDMPGFGAVASNGLIVRDGGRVLVVDTAWTDDQTAQILN WIKQEINLPVALAVVTHAHQDKMGGMDALHAAGIATYANALSNQLAPQEG MVAAOHSLTFAANGWVEPATAPNFGPLKVFYPGPGHTSDNITVGIDGTDIA FGGCLIKDSKAKSLGNLGDADTEHYAASARAFGAAFPKASMIVMSHSAPDSR AAITHTARMADKLR).

For protein production, pET30a-NDM-1 was transferred into E. coli BL21 (DE3), and the cells were grown in Luria-Bertani (LB) medium containing $50 \mu \mathrm{g} / \mathrm{mL}$ kanamycin. A single colony of $E$. coli BL21 (DE3)/pET30a-NDM-1 was inoculated into $100 \mathrm{~mL}$ of $\mathrm{LB}$ culture containing $50 \mu \mathrm{g} / \mathrm{mL}$ kanamycin and grown overnight at $37{ }^{\circ} \mathrm{C}$. The overnight culture was diluted in LB containing $50 \mu \mathrm{g} / \mathrm{mL}$ kanamycin and grown to midlogarithmic phase $\left(\mathrm{OD}_{600}=0.6\right)$. Protein expression was induced by adding $0.5 \mathrm{mM}$ isopropyl- $\beta$-D-thiogalactopyranoside (IPTG) and $0.5 \mathrm{mM} \mathrm{ZnSO}_{4}$ to the medium. After overnight induction at $15^{\circ} \mathrm{C}$ for $16 \mathrm{~h}$, the cells were harvested by centrifugation at $8000 \mathrm{rpm}$ for $15 \mathrm{~min}$ at $4{ }^{\circ} \mathrm{C}$ and then resuspended in buffer A ( $50 \mathrm{mM}$ Tris- $\mathrm{HCl}$ buffer, $\mathrm{pH}=8.0)$ containing $300 \mathrm{mM}$ $\mathrm{NaCl}, 20 \mathrm{mM}$ imidazole, $1 \%$ Triton X-100, $1 \mathrm{mM}$ DTT, and $1 \mathrm{mM} \mathrm{PMSF}$. After sonication, the mixture was centrifuged at $12,500 \mathrm{rpm}$ for $15 \mathrm{~min}$ at $4{ }^{\circ} \mathrm{C}$. The supernatant was filtered through a $0.45 \mu \mathrm{m}$ filter (Millipore, USA), loaded onto a Ni-IDA column, and pre-equilibrated with buffer A. The column was washed with buffer $\mathrm{A}$, and the protein was eluted by a linear gradient of imidazole from $50 \mathrm{mM}$ to $500 \mathrm{mM}$ in buffer A. The soluble NDM-1 protein was dialyzed against $2 \mathrm{~L}$ of $10 \mathrm{mM}$ PBS $(\mathrm{pH}=7.4)$ overnight at $4{ }^{\circ} \mathrm{C}$ and stored at $-80^{\circ} \mathrm{C}$. The purified enzyme was verified to be $>90 \%$ pure as assessed by SDS-PAGE. Protein concentration in the solution was measured with a Bradford protein assay kit, with bovine serum albumin as the standard. Zinc content in the purified NDM-1 was determined using the inductively coupled plasma-mass spectrometry (ICP-MS), ranging from 1.0 to 1.3 molar equivalents of zinc ion.

Preparation of apo-NDM-1. The apo form of NDM-1 was prepared by dialysis against EDTA as described by González et al. ${ }^{9}$. Briefly, apo-NDM-1 was derived from the purified NDM-1 obtained above by the two rounds of dialysis against 100 volumes of $10 \mathrm{mM}$ HEPES, $200 \mathrm{mM} \mathrm{NaCl}$, and $20 \mathrm{mM}$ EDTA at $\mathrm{pH}=7.4$ over a $12 \mathrm{~h}$ period under stirring. EDTA was removed from the resulting apoenzyme solution by three dialysis steps against 200 volumes of $10 \mathrm{mM}$ HEPES, $1 \mathrm{M} \mathrm{NaCl}$ $\mathrm{pH}=7.4$, Chelex 100 and finally three dialysis steps against 200 volumes of $50 \mathrm{mM}$ HEPES, $200 \mathrm{mM} \mathrm{NaCl}, \mathrm{pH}=7.4$, and Chelex 100. All buffer solutions used to prepare the apoenzymes were treated by stirring with Chelex 100 (Bio-Rad). Zinc content in the apoprotein samples was checked using ICP-MS, and apo-NDM-1 contains less than 0.2 molar equivalents of zinc ion.

Minimum inhibitory concentration (MIC). MIC values were identified through microdilution in sterilized 96-well polypropylene microtiter plates according to the broth microdilution guideline of the Clinical and Laboratory Standards Institute ${ }^{30}$. The test medium was Mueller-Hinton broth (MHB), and the strain concentrations were adjusted to $5 \times 10^{5} \mathrm{CFU} / \mathrm{mL}$. After $16 \mathrm{~h}$ of incubation at various concentrations of thanatin or other drugs at $37^{\circ} \mathrm{C}$, MIC was defined as the lowest concentration of antibiotic with no visible growth.

The MHB medium was supplemented with varying concentrations of $\mathrm{MgCl}_{2}$, $\mathrm{CaCl}_{2}$, DPA, or EDTA to explore the effects of divalent cations $\left(\mathrm{Mg}^{2+}, \mathrm{Ca}^{2+}\right)$ and metal-chelating agents (DPA, EDTA) on the MIC of thanatin against E. coli XJ141026.

Time-dependent killing. The time-kill curves for the NDM- 1 clinical isolates were identified using drop plate method according to basic microbiological protocol ${ }^{31}$. Bacterial cells were diluted to $1 \times 10^{6} \mathrm{CFU} / \mathrm{mL}$ and incubated with thanatin or ceftazidime for $0,0.5,1,3$ or $6 \mathrm{~h}$. At each time point, aliquots of each culture were collected, diluted and plated onto agar plates. After overnight culture, the CFU number was calculated from the colonies growing on the plates, and an untreated inoculum group was used as the negative control.

Sample preparation for membrane permeability assay. Thanatin-induced outer and inner membrane permeability was measured as previously described ${ }^{29}$. In brief, $10 \mathrm{~mL}$ of LB broth was inoculated with $0.1 \mathrm{~mL}$ of saturated E. coli XJ141026 culture and grown at $37^{\circ} \mathrm{C}$ overnight. Strains were diluted to $10^{8} \mathrm{CFU} / \mathrm{mL}$, and then thanatin was added to cell cultures to $0.8 \mu \mathrm{M}$. An equal volume of sterile PBS was added as the control. The strains were collected, washed, and resuspended in $5 \mathrm{mM}$ HEPES and $5 \mathrm{mM}$ glucose buffer $(\mathrm{pH}=7.2)$ at different time points.

Outer membrane permeability. Outer membrane permeability of thanatin was measured by the uptake of $1-\mathrm{N}$-phenylnaphthylamine (NPN) ${ }^{32}$. The prepared 
samples were incubated with NPN ( $8 \mu \mathrm{L}$ from a $500 \mu \mathrm{M}$ stock in acetone) for $30 \mathrm{~min}$ at $25^{\circ} \mathrm{C}$. The samples were then transferred to cuvettes. Fluorescence was measured using an F-2500 fluorescence spectrophotometer (Hitachi, Japan) at an excitation wavelength of $350 \mathrm{~nm}$ and an emission wavelength of $420 \mathrm{~nm}$.

Inner membrane permeability. The inner membrane permeability of thanatin was measured by the uptake of $\mathrm{PI}^{33}$. In brief, $10 \mu \mathrm{M}$ PI was added to the cells and incubated for $30 \mathrm{~min}$ at $25^{\circ} \mathrm{C}$. The fluorescence of the dye was monitored using a fluorescence spectrophotometer at an excitation wavelength of $535 \mathrm{~nm}$ and an emission wavelength of $617 \mathrm{~nm}$.

Scanning electron microscopy. E. coli XJ141026 culture at mid-logarithmic growth-phase was diluted in MHB to $1 \times 10^{8} \mathrm{CFU} / \mathrm{mL}$, cultured with $0.8,1.6$ and $3.2 \mu \mathrm{M}$ thanatin at $230 \mathrm{rpm}$ for $4 \mathrm{~h}$, harvested, and washed. As a control, bacteria were exposed to MHB without the peptide. Some specimens were observed in a scanning electron microscope (Hitachi S-3400N, Japan), and images were recorded.

Detection of $\mathbf{C a}^{2+}$ and LPS. The strain E. coli XJ141026 was tested in PBS without $\mathrm{Ca}^{2+}$ and $\mathrm{Mg}^{2+}$. Bacteria were grown to stationary phase, centrifuged, washed, resuspended in PBS $\left(3 \times 10^{10} \mathrm{CFU} / \mathrm{mL}\right)$, and incubated with 13 or $26 \mu \mathrm{M}$ thanatin at $37^{\circ} \mathrm{C}$. Aliquots of thanatin-treated and untreated cultures were obtained at 0 , $0.5,1,3$, and $6 \mathrm{~h}$. Then, $50 \mu \mathrm{L}$ of the culture was used to detect CFUs. The supernatant from the remaining cell suspension was collected by centrifugation and filtered through a $0.22 \mu \mathrm{m}$ filter (Millipore, USA). LPS release was assessed using a chromogenic limulus amebocyte lysate assay (Xiamen Bioendo Technology, Co. Ltd., China) $)^{34}$. The amount of $\mathrm{Ca}^{2+}$ was quantified using an Amplite Colorimetric Calcium Quantitation Kit (AAT Bioquest Inc., California, USA), which has a dye that changes color when bound to $\mathrm{Ca}^{2+}$. The analyses were conducted in 96-well microtiter plates according to the manufacturer's protocols.

Effects of excess $\mathrm{Ca}^{2+}$ on bacterial LPS release and CFUs. E. coli XJ141026 was tested in PBS with $0.1,0.5$, and $1 \mathrm{mM} \mathrm{Ca}^{2+}$ in the absence or presence of 13 or $26 \mu \mathrm{M}$ thanatin to explore the effect of $\mathrm{Ca}^{2+}$ availability on LPS release from cells treated with thanatin. Bacterial counts and LPS release were detected after $6 \mathrm{~h}$ as described above

Isothermal titration calorimetry (ITC). Microcalorimetric measurements of the binding of thanatin or divalent cations $\left(\mathrm{Mg}^{2+}, \mathrm{Ca}^{2+}\right)$ to LPS were performed on a MicroCal Auto-ITC200 instrument (Malvern Instruments, Malvern, UK) ${ }^{35}$. LPS (E. coli serotype 055:B5, Sigma, USA) was dissolved in $20 \mathrm{mM}$ Tris- $\mathrm{HCl}(\mathrm{pH}=6.8)$ or $10 \mathrm{mM}$ PBS $(\mathrm{pH}=7.4)$, vortexed vigorously for $15 \mathrm{~min}$, and sonicated for $15 \mathrm{~min}$ at $60^{\circ} \mathrm{C}$. The LPS solution was sonicated for $5 \mathrm{~min}$ prior to use. Thanatin was dissolved in Tris- $\mathrm{HCl}(\mathrm{pH}=6.8)$ and titrated into LPS in Tris- $\mathrm{HCl}(\mathrm{pH}=6.8)$. Divalent cations $\left(\mathrm{Mg}^{2+}, \mathrm{Ca}^{2+}\right)$ were dissolved in PBS $(\mathrm{pH}=7.4)$ and titrated into LPS in PBS $(\mathrm{pH}=7.4)$. All samples were degassed for $10 \mathrm{~min}$ in a sonication bath before the experiments. These experiments were performed at $25^{\circ} \mathrm{C}$. The generated peaks were integrated using Origin 7.0 software. The errors for all the reported thermodynamic parameters were estimated through Monte Carlo simulation with the standard errors of three experiments.

Detection of NDM-1 protein levels and hydrolytic activity. An overnight culture of E. coli XJ141026 was diluted to $1: 2$ in $\mathrm{LB}$ and incubated at $37^{\circ} \mathrm{C}$ with $0.8,1.6$, and $3.2 \mu \mathrm{M}$ thanatin or colistin under shaking at $250 \mathrm{rpm}$ for 6 or $12 \mathrm{~h}$. At given intervals, the culture supernatant was collected by centrifugation at $12,000 \mathrm{rpm}$ and $4{ }^{\circ} \mathrm{C}$ for $20 \mathrm{~min}$ and filtered through $0.22 \mu \mathrm{m}$ filters to eliminate bacteria. NDM-1 level in the filtered supernatant was measured using a specific ELISA kit (Shanghai Enzyme-linked Biotechnology Co., Ltd., China) and western blot analysis. Imipenem hydrolysis in the filtered supernatant at $6 \mathrm{~h}$ was monitored using a Biotek powerwave $\mathrm{HT}$ microplate spectrophotometer at $30^{\circ} \mathrm{C}$ by determining the changes in absorbance at $300 \mathrm{~nm}$, with a final substrate concentration of $100 \mu \mathrm{M}$.

Thanatin- and colistin-treated E. coli XJ141026 cell precipitates were harvested at $6 \mathrm{~h}$ and washed twice with $20 \mathrm{mM}$ Tris- $\mathrm{HCl}(\mathrm{pH}=7.4)$. The washed cells were resuspended in the lysis buffer (Jiangsu KeyGEN BioTECH Corp., Ltd., China) supplemented with $1 \mathrm{mM}$ PMSF, $1 \mathrm{mM}$ DTT at $4{ }^{\circ} \mathrm{C}$ for $10 \mathrm{~min}$, and disrupted by sonication. Cell debris was removed by centrifugation at $12,000 \mathrm{rpm}$ and $4^{\circ} \mathrm{C}$ for $20 \mathrm{~min}$. Soluble total protein concentration was determined and normalized with the Pierce BCA Protein Assay Kit (Thermo Fisher Scientific, Waltham, MA, USA). NDM-1 levels in the cells were measured by SDS-PAGE followed by western blot analysis. The primary antibody against NDM-1 was obtained from Detai Bio-Tech Co., Ltd. by immunizing New Zealand white rabbits with purified NDM-1 protein and further detected by horseradish peroxidase-conjugated anti-rabbit secondary antibody (Santa Cruz Biotechnology Inc., USA). Anti-GroEL antibody (Abcam, ab82592) was used to verify protein loading transferred to the membranes. To clearly normalize the levels of NDM-1, we investigated the two proteins on the same membrane. After detecting the bands of NDM-1, the stripping buffer was used to remove the primary and secondary antibodies from the membrane according to the manufacturer's protocol (Beijing Solarbio Science \& Technology Co., Ltd., China). The stripped membrane was then used to detect the levels of
GroEL. Protein band intensities were quantified from polyvinylidene difluoride membranes with ImageJ software.

The cell pellet was washed and resuspended in $20 \mathrm{mM}$ Tris- $\mathrm{HCl}(\mathrm{pH}=7.4)$ to evaluate imipenem hydrolysis in bacterial cell precipitates. The concentrations were equalized by adjusting the absorbance values to $\mathrm{OD}_{600}=0.3$ in the same buffer. After $50 \mu \mathrm{L}$ of the diluted bacterial cell suspension was transferred to a 96-well plate, $50 \mu \mathrm{L}$ of $200 \mu \mathrm{M}$ imipenem was added to measure the hydrolytic activity of NDM- 1 and $50 \mu \mathrm{L}$ of $20 \mathrm{mM}$ Tris- $\mathrm{HCl}(\mathrm{pH}=7.4)$ was added as blank. The assays were monitored at $300 \mathrm{~nm}$ by using a Biotek powerwave HT microplate spectrophotometer at $30^{\circ} \mathrm{C}$. Data were corrected by subtracting the absorbance values obtained from the blanks.

NDM-1 inhibition assays. $\mathrm{IC}_{50}$ value and $K_{\mathrm{i}}$ were detected to evaluate the inhibitory effect of thanatin. Thanatin was dissolved in $50 \mathrm{mM}$ HEPES $(\mathrm{pH}=6.8)$ containing $0.05 \%$ Tween-20 to a final concentration of $800 \mu \mathrm{M}$ and diluted in the same buffer. The purified NDM-1 protein dissolved in $50 \mathrm{mM}$ HEPES $(\mathrm{pH}=7.4)$ containing $0.05 \%$ Tween-20 supplemented with $10 \mu \mathrm{M} \mathrm{ZnSO}$ was pre-incubated with different concentrations of thanatin for $20 \mathrm{~min}$ at $30^{\circ} \mathrm{C}$. The assay was initiated by adding imipenem to the mixture of NDM- 1 and thanatin, with a final enzyme concentration of $1 \mathrm{nM}$, imipenem of $100 \mu \mathrm{M}$ and 12 different concentrations of thanatin. The change in absorbance at $300 \mathrm{~nm}$ was monitored for $30 \mathrm{~min}$ in 96-well plates at $30^{\circ} \mathrm{C}$. The initial rate of reaction for each inhibitor concentration was calculated from the slope of the initial linear phase of the respective time course. The $\mathrm{IC}_{50}$ value was obtained by plotting the residual enzyme activity on imipenem (\%) vs. inhibitor concentration $\left(\log _{10}\right) . K_{\mathrm{i}}$ was obtained by nonlinear fitting of the initial rates $\left(\mathrm{V}_{0}\right)$ of the hydrolysis of imipenem $(100,200,400,800$, and $1600 \mu \mathrm{M}$ ) by $1 \mathrm{nM} \mathrm{NDM}-1$ in the absence and presence of three concentrations of thanatin. The best fits were obtained with the competitive inhibition model by using the equation $V_{0}=\left(V_{\max } \times[S]\right) /\left(K_{\mathrm{m}} \times\left(1+[I] / K_{\mathrm{i}}\right)+[S]\right) . K_{\mathrm{m}},[I]$, and $[S]$ in the equation correspond to Michaelis-Menten constant, thanatin concentration, and imipenem concentration, respectively. The kinetics parameters $K_{\mathrm{m}} /$ $V_{\max } / K_{\text {cat }}$ were calculated by fitting the data into the double reciprocal Lineweaver-Burk plots. GraphPad 5.0 was used for data analysis.

$\mathbf{Z n}^{2+}$ restoration assays. Purified-NDM-1 $(4 \mathrm{nM})$ supplemented with $10 \mu \mathrm{M}$ $\mathrm{ZnSO}_{4}$ was mixed with thanatin $(200 \mu \mathrm{M})$ in 1:1 volume ratio. After incubating for $20 \mathrm{~min}$ at $30^{\circ} \mathrm{C}, 50 \mu \mathrm{L}$ of the mixture was added to the 96-well plate. The total volume was adjusted to $100 \mu \mathrm{L}$ with the following final concentrations: $1 \mathrm{nM}$ NDM-1, $50 \mu \mathrm{M}$ thanatin, $100 \mu \mathrm{M}$ imipenem and $\mathrm{ZnSO}_{4}$ ranging from $0.1 \mu \mathrm{M}$ to $800 \mu \mathrm{M}$. The absorbance at $300 \mathrm{~nm}$ was monitored for $30 \mathrm{~min}$ at $30^{\circ} \mathrm{C}$. Percent residual activity was calculated from the thanatin-free $\mathrm{control}^{28}$.

Microscale thermophoresis (MST). The $K_{\mathrm{d}}$ values of the binding of NDM- 1 to $\mathrm{Zn}^{2+}$, thanatin and colistin were measured using a Monolith NT.115 Pico

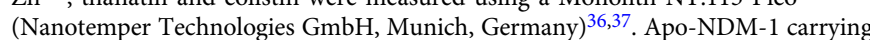
a polyhistidine-tag (His-tag) was labeled with the RED-tris-NTA secondgeneration dye for $30 \mathrm{~min}$ at room temperature in the dark according to the manufacturer's instructions (Monolith His-tag Labeling Kit RED-tris-NTA 2nd generation, Nanotemper Technologies $\mathrm{GmbH}$ ). $\mathrm{Zn}^{2+}$, thanatin, and colistin solutions were serially diluted in the reaction buffer $(50 \mathrm{mM}$ HEPES buffer $[\mathrm{pH}=7.4]$ containing $0.05 \%$ Tween- 20 for $\mathrm{Zn}^{2+}$ and colistin; $50 \mathrm{mM}$ HEPES [pH $\left.=6.8\right]$ containing $0.05 \%$ Tween-20 for thanatin). Then, $100 \mathrm{nM}$ labeled NDM-1 protein was added to the serial dilution of the compound in a 1:1 volume ratio. After incubation for $30 \mathrm{~min}$ at room temperature, the samples were examined with Monolith NT.115 in Premium Capillaries (MO-K025) at medium MST power and $5 \% \mathrm{LED} /$ excitation power. $K_{\mathrm{d}}$ values were determined using the Monolith Affinity Analysis $K_{\mathrm{d}}$ fit from triplicate experiments.

Preparation of holo-NDM-1 and ICP-MS assay. To prepare holo-NDM-1 ${ }^{38}$, we incubated the purified NDM-1 with 2.5 molar equivalents of $\mathrm{Zn}^{2+}$ in the ICP-MS buffer (50 mM HEPES, $200 \mathrm{mM} \mathrm{NaCl}, \mathrm{pH}=7.4$ ) for $1 \mathrm{~h}$ on ice. The reconstituted holo-NDM-1 was dialyzed ( $10 \mathrm{kDa}$ MWCO) overnight at $4{ }^{\circ} \mathrm{C}$ against 100 volumes of Chelex-treated ICP-MS buffer containing $0.05 \%$ Tween-20 and desalted in the same buffer by using $7 \mathrm{kDa}$ MWCO Zeba ${ }^{\mathrm{m}}$ Spin Desalting Columns (Thermo Fisher Scientific) to remove excess $\mathrm{Zn}^{2+}$

Following the exchange, the holo-NDM- 1 was diluted to $4 \mu \mathrm{M}$ and incubated with $0,20,40$, and $80 \mu \mathrm{M}$ thanatin for $3 \mathrm{~h}$ at room temperature with gentle shaking The thanatin-treated holo-NDM-1 was buffer-exchanged again to remove any unbound $\mathrm{Zn}^{2+}$ and thanatin as described above. The final protein concentration was determined using the NDM-1 ELISA kit (Shanghai Enzyme-linked Biotechnology Co., Ltd., China). The final protein was diluted to $1 \mu \mathrm{M}$ and digested in $5 \%$ nitric acid at $80^{\circ} \mathrm{C}$ for $1 \mathrm{~h}$. The digested samples were measured with a Perkin Elmer NexION ${ }^{m}$ 350D ICP-MS ${ }^{28,38}$. The concentrations of $\mathrm{Zn}^{2+}$ were calculated according to the calibration curve, and data were corrected by subtracting the values of $\mathrm{Zn}^{2+}$ concentration obtained from the background control buffer. Finally, the molar equivalents of $\mathrm{Zn}^{2+}$ were calculated from the ratio of $\mathrm{Zn}^{2+}$ concentration to the enzyme concentration. 
Fractional inhibitory concentration (FIC). Synergy in vitro was assessed by checkerboard assays. The plates were set up with serial doubling dilutions of thanatin and meropenem or imipenem at various concentrations. Following incubation, the synergistic/additive effect was determined by calculating the FIC indices (FICI) according to the formula: $\mathrm{FICI}=(\mathrm{MIC}$ of $\mathrm{A}$ in combination/MIC of A) $+($ MIC of B in combination/MIC of B). The synergy or additive was defined according to standard criteria (FICI $\leq 0.5$ was defined as synergistic; $0.5<\mathrm{FICI} \leq 1$ was defined as additive; $1<\mathrm{FICI} \leq 4$ was defined as indifference; $\mathrm{FICI}>4$ was defined as antagonism $)^{39}$.

The kill curves were determined as mentioned above to investigate the bactericidal activity of the combination treatment. Bacterial cells were diluted to $1 \times 10^{6} \mathrm{CFU} / \mathrm{mL}$ and incubated with thanatin, carbapenem or their combination for $16 \mathrm{~h}$. CFUs were counted.

Cytotoxicity. HUVECs (ATCC-CRL1730) were cultured in Dulbecco's modified Eagle medium (DMEM) containing 10\% fetal bovine serum (FBS) and penicillin-streptomycin (100 units/mL). HPAEpiCs (ScienCell Research Lab., Catalog\#3200, San Diego, CA) were incubated in alveolar epithelial cell medium (AEpiCM, ScienCell Research Lab., Catalog\#3201). HUVECs and HPAEpiCs were seeded into 96 -well plates at $5 \times 10^{3}$ cells/well for $24 \mathrm{~h}$. The cells were washed twice with PBS and once with the corresponding serum-free culture medium. The cells were treated with a range of concentrations of thanatin or colistin in the serum-free culture medium for $24 \mathrm{~h}$. Cytotoxicity was analyzed using Cell Counting Kit (CCK8) (Dojindo, Kumamoto, Japan).

Mouse primary cortical neurons were isolated and plated at a density of $1.5 \times$ $10^{5}$ cells $/ \mathrm{cm}^{2}$ in wells pre-coated with poly-L-lysine $(25 \mu \mathrm{g} / \mathrm{mL})$ and seeded in DMEM containing $10 \%$ FBS in a humidified $5 \% \mathrm{CO}_{2}$ incubator at $37^{\circ} \mathrm{C}$. The DMEM was replaced with Neurobasal medium (Gibco-12348-017, Thermo Fisher Scientific, Waltham, MA, USA) supplemented with 2\% B27 (Gibco-17504044) after $4 \mathrm{~h}$ of plating. The cells were used for experiments after culturing for $7 \mathrm{~d}$ in an incubator under constant temperature and humidity. The cells were treated with $50 \mu \mathrm{M}$ thanatin for $24 \mathrm{~h}$, with the addition of an equal volume of culture medium as a negative control and $0.1 \%$ Triton X-100 as a positive control. PI and Hoechst 33342 were used to detect plasma membrane permeability and cell death. The fluorescence of the dye was observed with an inverted fluorescence microscope (ECLIPSE Ti-S, Nikon, Japan).

Animal studies. Male BALB/c mice aged 8-10 weeks and weighing $18-22 \mathrm{~g}$ were used. The experimental and animal care procedures were approved by the animal care and use committee of the Fourth Military Medical University.

Mouse pneumonia model. The mice were anesthetized with $10 \mathrm{mg} / \mathrm{mL}$ pentobarbital via intraperitoneal injection at a dose of $60 \mathrm{mg} / \mathrm{kg}$ and intranasally infected with $1 \times 10^{9} \mathrm{CFU}$ E. coli XJ141026 or K. pneumoniae XJ155017 in $30 \mu \mathrm{L}$ of MHB. After bacterial challenge, E. coli XJ141026-infected mice were intraperitoneally injected with $6 \mathrm{mg} / \mathrm{kg}$ thanatin at 1 and $6 \mathrm{~h}$. K. pneumoniae XJ155017-infected mice were intraperitoneally injected with 3,6 , or $9 \mathrm{mg} / \mathrm{kg}$ thanatin at 1 and $6 \mathrm{~h}$. Bacterial numbers in the lungs were recorded at $24 \mathrm{~h}$ post infection as described above. The left lungs were fixed with $10 \%$ formaldehyde and embedded in paraffin for hematoxylin and eosin (H\&E) staining. The survival of 10 mice in each group was monitored for $7 \mathrm{~d}$ after infection. Cumulative survival rate was determined.

BALF was collected after thanatin treatment at 1 and $6 \mathrm{~h}$ and filtered through a $0.22 \mu \mathrm{m}$ filter. The bacterial numbers and LPS levels were measured as described above.

Mouse sepsis model. A sepsis model was established through an intraperitoneal administration of $4 \times 10^{7} \mathrm{CFU}$ E. coli XJ141026 in $0.1 \mathrm{~mL}$ of MHB. After bacterial challenge, the mice were treated with a 1,3 , or $6 \mathrm{mg} / \mathrm{kg}$ thanatin at 1 and $6 \mathrm{~h}$. Six mice in each group were anesthetized with $10 \mathrm{mg} / \mathrm{mL}$ pentobarbital via intraperitoneal injection at a dose of $60 \mathrm{mg} / \mathrm{kg}$ to assess bacterial clearance. Afterward, $100 \mu \mathrm{L}$ of the blood samples were collected from retro-orbital sinus after bacterial challenge for $24 \mathrm{~h}$. The lungs, livers, and spleens were harvested aseptically from each sacrificed animal. These organs were weighed and homogenized in a sterile saline solution. The homogenates were plated onto agar plates at appropriate diluted concentrations. Colonies were counted after $18 \mathrm{~h}$ of incubation at $37^{\circ} \mathrm{C}$. Colony counts in the tissues and blood were expressed as CFU/g. The survival of 10 mice in each group was monitored for 7 days after infection. Cumulative percentage survival was calculated. Parts of the lung, liver, and spleen were harvested, washed with sterile PBS, and fixed in $10 \%$ formaldehyde for $24 \mathrm{~h}$. Their morphologies were observed using H\&E staining.

Synergism of thanatin and meropenem in the sepsis model. BALB/c mice were infected intraperitoneally with $8 \times 10^{7} \mathrm{CFU}$ of E. coli XJ141026 in $0.1 \mathrm{~mL}$ of MHB. The mice were treated with $10 \mathrm{mg} / \mathrm{kg}$ meropenem, $0.1 \mathrm{mg} / \mathrm{kg}$ thanatin, or their combination at $1 \mathrm{~h}$ post challenge. The model group was intraperitoneally injected with an equivalent volume of PBS. Six mice in each group were sacrificed after bacterial challenge for $24 \mathrm{~h}$ to assess bacterial clearance in the spleens and livers. In addition, the survival rates were detected as described above.
Statistical analysis. The results are expressed as means \pm s.e.m. Unpaired twotailed $t$-tests, one-way ANOVA, two-way ANOVA or log-rank test were used for statistical evaluations. A probability $(P)$ value of 0.05 was considered indicative of statistical significance.

Reporting summary. Further information on research design is available in the Nature Research Reporting Summary linked to this article.

\section{Data availability}

The source data underlying Figs. 1a-d, 2, 3a-d, 4, 5, and 6b-f, and Supplementary Figs. 1 2, 3a-d, 4a, 7a, b, 8a-f, 9, 10,11, and 12 are provided in the Source Data file. The original data of the unprocessed blot and gel images are also available in the Source Data file. The source data can also be found at figshare (https://doi.org/10.6084/m9.figshare.8481098.vl). All other data that support the findings of this study are available from the corresponding author upon request.

Received: 24 August 2018 Accepted: 16 July 2019

Published online: 06 August 2019

\section{References}

1. Johnson, A. P. \& Woodford, N. Global spread of antibiotic resistance: the example of New Delhi metallo-beta-lactamase (NDM)-mediated carbapenem resistance. J. Med. Microbiol. 62, 499-513 (2013).

2. Kumarasamy, K. K. et al. Emergence of a new antibiotic resistance mechanism in India, Pakistan, and the UK: a molecular, biological, and epidemiological study. Lancet Infect. Dis. 10, 597-602 (2010).

3. Rolain, J. M., Parola, P. \& Cornaglia, G. New Delhi metallo-beta-lactamase (NDM-1): towards a new pandemia? Clin. Microbiol. Infect. 16, 1699-1701 (2010).

4. Khan, A. U., Maryam, L. \& Zarrilli, R. Structure, Genetics and Worldwide Spread of New Delhi Metallo-beta-lactamase (NDM): a threat to public health. BMC Microbiol. 17, 101 (2017).

5. Zhong, L. L. et al. Coproduction of MCR-1 and NDM-1 by colistin-resistant Escherichia coli Isolated from a healthy individual. Antimicrob. Agents Chemother. 61, e01962-16 (2017).

6. Delgado-Blas, J. F., Ovejero, C. M., Abadia-Patino, L. \& Gonzalez-Zorn, B. Coexistence of mcr-1 and blaNDM-1 in Escherichia coli from Venezuela. Antimicrob. Agents Chemother. 60, 6356-6358 (2016).

7. Stewart, A. C. et al. Clinical Variants of New Delhi metallo-beta-Lactamase are evolving to overcome zinc scarcity. ACS Infect. Dis. 3, 927-940 (2017).

8. Brem, J. et al. Structural basis of metallo-beta-lactamase, serine-beta-lactamase and penicillin-binding protein inhibition by cyclic boronates. Nat. Commun. 7, 12406 (2016).

9. Gonzalez, L. J. et al. Membrane anchoring stabilizes and favors secretion of New Delhi metallo-beta-lactamase. Nat. Chem. Biol. 12, 516-522 (2016).

10. Brophy, M. B., Hayden, J. A. \& Nolan, E. M. Calcium ion gradients modulate the zinc affinity and antibacterial activity of human calprotectin. J. Am. Chem. Soc. 134, 18089-18100 (2012)

11. Corbin, B. D. et al. Metal chelation and inhibition of bacterial growth in tissue abscesses. Science 319, 962-965 (2008).

12. Fehlbaum, P. et al. Structure-activity analysis of thanatin, a 21-residue inducible insect defense peptide with sequence homology to frog skin antimicrobial peptides. Proc. Natl Acad. Sci. USA 93, 1221-1225 (1996).

13. Hou, Z. et al. Underlying mechanism of in vivo and in vitro activity of Cterminal-amidated thanatin against clinical isolates of extended-spectrum beta-lactamase-producing Escherichia coli. J. Infect. Dis. 203, 273-282 (2011).

14. Clifton, L. A. et al. Effect of divalent cation removal on the structure of gramnegative bacterial outer membrane models. Langmuir 31, 404-412 (2015).

15. Groundwater, P. W. et al. New Delhi metallo-beta-lactamase-1: structure, inhibitors and detection of producers. Future Med. Chem. 8, 993-1012 (2016).

16. Gonzalez, J. M. et al. Metallo-beta-lactamases withstand low $\mathrm{Zn}$ (II) conditions by tuning metal-ligand interactions. Nat. Chem. Biol. 8, 698-700 (2012).

17. Giles, N. M. et al. Metal and redox modulation of cysteine protein function. Chem. Biol. 10, 677-693 (2003).

18. Koch-Weser, J. et al. Adverse effects of sodium colistimethate. Manifestations and specific reaction rates during 317 courses of therapy. Ann. Intern. Med. 72, 857-868 (1970)

19. Landman, D., Georgescu, C., Martin, D. A. \& Quale, J. Polymyxins revisited. Clin. Microbiol. Rev. 21, 449-465 (2008).

20. Mercuro, N. J., Davis, S. L., Zervos, M. J. \& Herc, E. S. Combatting resistant enterococcal infections: a pharmacotherapy review. Expert Opin. Pharmacother. 19, 979-992 (2018).

21. Zhang, Y., Lin, X. \& Bush, K. In vitro susceptibility of beta-lactamaseproducing carbapenem-resistant Enterobacteriaceae (CRE) to eravacycline. $J$. Antibiot. (Tokyo) 69, 600-604 (2016). 
22. Zhang, Y., Kashikar, A. \& Bush, K. In vitro activity of plazomicin against betalactamase-producing carbapenem-resistant Enterobacteriaceae (CRE). J. Antimicrob. Chemother. 72, 2792-2795 (2017).

23. Sinha, S., Zheng, L., Mu, Y., Ng, W. J. \& Bhattacharjya, S. Structure and interactions of a host defense antimicrobial peptide thanatin in lipopolysaccharide micelles reveal mechanism of bacterial cell agglutination. Sci. Rep. 7, 17795 (2017).

24. Vetterli, S. U. et al. Thanatin targets the intermembrane protein complex required for lipopolysaccharide transport in Escherichia coli. Sci. Adv. 4, eaau2634 (2018).

25. Lienard, B. M. et al. Structural basis for the broad-spectrum inhibition of metallo-beta-lactamases by thiols. Org. Biomol. Chem. 6, 2282-2294 (2008).

26. Wang, R. et al. Bismuth antimicrobial drugs serve as broad-spectrum metallobeta-lactamase inhibitors. Nat. Commun. 9, 439 (2018).

27. Ju, L. C., Cheng, Z., Fast, W., Bonomo, R. A. \& Crowder, M. W. The continuing challenge of metallo-beta-lactamase inhibition: mechanism matters. Trends Pharmacol. Sci. 39, 635-647 (2018).

28. King, A. M. et al. Aspergillomarasmine A overcomes metallo-beta-lactamase antibiotic resistance. Nature 510, 503-506 (2014).

29. Ma, B. et al. The Disulfide Bond of the Peptide Thanatin Is Dispensible for Its Antimicrobial Activity In Vivo and In Vitro. Antimicrob. Agents Chemother. 60, 4283-4289 (2016).

30. CLSI. Methods for Dilution Antimicrobial Susceptibility Tests for Bacteria That Grow Aerobically. Clinical Laboratory Standards Institute, M07-A09, (2012).

31. Herigstad, B., Hamilton, M. \& Heersink, J. How to optimize the drop plate method for enumerating bacteria. J. Microbiol. Methods 44, 121-129 (2001).

32. Hancock, R. E., Farmer, S. W., Li, Z. S. \& Poole, K. Interaction of aminoglycosides with the outer membranes and purified lipopolysaccharide and OmpF porin of Escherichia coli. Antimicrob. Agents Chemother. 35, 1309-1314 (1991).

33. Yarlagadda, V., Akkapeddi, P., Manjunath, G. B. \& Haldar, J. Membrane active vancomycin analogues: a strategy to combat bacterial resistance. J. Med. Chem. 57, 4558-4568 (2014)

34. Lindsay, G. K., Roslansky, P. F. \& Novitsky, T. J. Single-step, chromogenic Limulus amebocyte lysate assay for endotoxin. J. Clin. Microbiol. 27, 947-951 (1989).

35. Khan, A. U., Ali, A., Danishuddin, Srivastava, G. \& Sharma, A. Potential inhibitors designed against NDM-1 type metallo-beta-lactamases: an attempt to enhance efficacies of antibiotics against multi-drug-resistant bacteria. Sci. Rep. 7, 9207 (2017).

36. Bartoschik, T. et al. Near-native, site-specific and purification-free protein labeling for quantitative protein interaction analysis by MicroScale Thermophoresis. Sci. Rep. 8, 4977 (2018).

37. Lata, S., Gavutis, M., Tampe, R. \& Piehler, J. Specific and stable fluorescence labeling of histidine-tagged proteins for dissecting multi-protein complex formation. J. Am. Chem. Soc. 128, 2365-2372 (2006).

38. Chan, A. N. et al. Role for dithiolopyrrolones in disrupting bacterial metal homeostasis. Proc. Natl Acad. Sci. USA 114, 2717-2722 (2017).
39. Doern, C. D. When does 2 plus 2 equal 5? A review of antimicrobial synergy testing. J. Clin. Microbiol. 52, 4124-4128 (2014).

\section{Acknowledgements}

We thank Xiuli Xu and Shan Zhou for providing us with NDM-1 strains from the Department of Clinical Laboratory Medicine of Xijing Hospital. This work was supported by grants from the National Natural Science Foundation of China (no. 81673477, 81471997, and 81001460).

\section{Author contributions}

Z.H., B.M., and X.X.L. designed the experiments; Y.Z. and M.Z.W. accomplished the expression and purification of NDM-1 protein; B.M., L.S.L., M.Z.W., and X.Y.X. performed the experiments; Y.H. and M.K.L analyzed the data; C.F., Z.H., and B.M. wrote the manuscript. All authors reviewed the manuscript.

\section{Additional information}

Supplementary Information accompanies this paper at https://doi.org/10.1038/s41467019-11503-3.

Competing interests: The authors declare no competing interests.

Reprints and permission information is available online at http://npg.nature.com/ reprintsandpermissions/

Peer review information: Nature Communications thanks Alejandro Vila and other anonymous reviewer(s) for their contribution to the peer review of this work. Peer reviewer reports are available.

Publisher's note: Springer Nature remains neutral with regard to jurisdictional claims in published maps and institutional affiliations.

(c) (i) Open Access This article is licensed under a Creative Commons Attribution 4.0 International License, which permits use, sharing, adaptation, distribution and reproduction in any medium or format, as long as you give appropriate credit to the original author(s) and the source, provide a link to the Creative Commons license, and indicate if changes were made. The images or other third party material in this article are included in the article's Creative Commons license, unless indicated otherwise in a credit line to the material. If material is not included in the article's Creative Commons license and your intended use is not permitted by statutory regulation or exceeds the permitted use, you will need to obtain permission directly from the copyright holder. To view a copy of this license, visit http://creativecommons.org/ licenses/by/4.0/.

(C) The Author(s) 2019 